\title{
Secondary care in oral health in small municipalities: a cross-sectional evalu- ation of demand $x$ access
}

\author{
Atenção secundária em saúde bucal em municípios de pequeno porte: uma avaliação transversal da demanda $x$ \\ acesso
}

Wellen Carla da Luz Benfica COSTA ${ }^{1}$

(iD) ORCID iD 0000-0001-6068-9637

Marcos Azeredo Furquim WERNECK²

(iD) ORCID iD 0000-0002-4160-018X

Andréa Clemente PALMIER²

(iD) ORCID iD 0000-0002-1186-1688

\section{ABSTRACT}

\section{Objective}

To know the demand and access to specialized procedures in Oral Health in 10 municipalities in the region of Guanhães, Minas Gerais, Brazil, which do not have a Dental Specialty Center.

\begin{abstract}
Methods
Cross-sectional study was conducted with 30 dental surgeons of the Primary Care system. These dentists recorded all the patients who were treated from July to November 2016, and who were shown to be in need of being assigned to specialized procedures in oral health. The descriptive analysis was developed in the software SPSS for Windows version 18.0. The study was approved by the Research Ethics Committee of the Federal University of Minas Gerais (ruling 1.615.701).
\end{abstract}

\section{Results}

1085 patients assigned for specialized procedures in Oral Health were evaluated. The majority of these patients were women (56.6\%), within an age-range from 13-34 years (51.9\%). Among the specialties evaluated, 61\% of the patients presented the need for endodontic treatment, with the most compromised tooth being the first permanent molar (33.2\%). The outcomes were recorded for 435 (40.1\%) patients. Among these, $19.8 \%$ of the procedures were performed in the health unit itself and in $45.5 \%$ extractions were performed.

\section{Conclusion}

Limited access to specialized Oral Health procedures was verified. To enable the Oral Health National Policy to consider the specificities of such regions, it is suggested that the scope of action of the oral health teams in primary care is expanded, or that less expensive specialized services are created, so that the access to this level of oral health is assured to all referred patients.

Indexing terms: Secondary care. Integrality in health. Oral health. Unified health system.

\section{RESUMO}

\section{Objetivo}

Conhecer a demanda e o acesso para procedimentos especializados em Saúde Bucal em 10 municípios da região de Guanhães, Minas Gerais, que não possuem Centro de Especialidades Odontológicas.

\section{Métodos}

Estudo transversal realizado com 30 cirurgiões-dentistas da Atenção Primária que registraram todos os pacientes que foram atendidos no período de julho a novembro de 2016 que apresentassem necessidade de indicação para procedimentos especializados em saúde bucal. A análise descritiva foi desenvolvida no programa SPSS for Windows versão 18.0. O estudo foi aprovado pelo Comitê de Ética em Pesquisa da Universidade Federal de Minas Gerais (parecer 1.615.701).

\section{Resultados}

Foram avaliados 1085 pacientes com indicação para procedimentos especializados em Saúde Bucal. A maioria era do sexo feminino (56,6\%), com idade entre 13 e 34 anos (52,6\%). Das especialidades avaliadas, $61 \%$ dos pacientes apresentaram necessidade de tratamento endodôntico, sendo que o dente mais acometido foi o primeiro molar permanente $(47,2 \%)$. Os desfechos foram registrados para 435 (40,1\%) pacientes. Nesses, $19,8 \%$ dos procedimentos foram realizados na própria unidade de saúde e $45,5 \%$ foram submetidos à exodontia.

\section{Conclusão}

Verificou-se a limitação de acesso aos procedimentos especializados em Saúde Bucal. Para que a Política Nacional de Saúde Bucal possa contemplar especificidades de regiões como essa, sugere-se a ampliação do escopo de ação das equipes de saúde bucal na atenção primária ou da criação de serviços especializados de menor monta, a fim de garantir acesso a este nível em saúde bucal para todos os pacientes.

Termos de indexação: Atenção secundária à saúde. Integralidade em Saúde. Saúde bucal. Sistema único de saúde.

\footnotetext{
${ }^{1}$ Universidade Federal de Minas Gerais, Faculdade de Odontologia, Programa de Pós-Graduação em Saúde Pública. Belo Horizonte, MG, Brasil.

${ }^{2}$ Universidade Federal de Minas Gerais, Faculdade de Odontologia, Departamento de Odontologia Social e Preventiva. Av. Presidente Antônio Carlos, 6627, Pampulha, 31270-901, Belo Horizonte, MG, Brasil. Correspondência para / Correspondence to: AC PALMIER. E-mail: < acpalmier@terra.com. br>.

$\boldsymbol{\nabla} \nabla \boldsymbol{V}$

Como citar este artigo / How to cite this article

Costa WCLB, Werneck MAF, Palmier AC. Secondary care in oral health in small municipalities: a cross-sectional evaluation of demand x access. RGO, Rev Gaúch Odontol. 2018;66(1):70-76. http://dx.doi.org/10.1590/1981-863720180001000093348
} 


\section{INTRODUCTION}

Health care is a fundamental right of the Brazilian people, guaranteed by the Federal Constitution of 1988, which established the creation of the Brazilian National Health System (SUS), and proposed a care model with universal, egalitarian, full (integral), and decentralized access $^{1-2}$. In spite of the advances verified over the last few years, fragmentation of the system still persists and is a challenge to the consolidation of integrality. A proposal for overcoming this problem is the constitution of Health Care Networks ( $\mathrm{HCN}$ ) in an interconnected arrangement of devices coordinated by primary health care (as the port of entry into the system). According to the decentralization guideline, the HCN would obey a regional arrangement with a population and territorial basis ${ }^{3}$. The HCNs are composed of three levels of care, coordinated by the PHC in a polyarchic, horizontalized and interdependent arrangement ${ }^{4}$.

The offer of oral health services must be made equally and fully available to all Brazilians. The National Oral Health Policy (NOHP), With the fantasy name of "Smiling Brazil", seeks to rescue the doctrines and principles of SUS for the oral health services, by means of the qualification of care, constitution of networks, and guarantee of integral care, by joining preventive and health promotion actions with the curative actions necessary at the different levels of complexity of the system ${ }^{5}$.

One of the main strategies for guaranteeing the continuity of oral health care and rehabilitation is the implementation of Dental Specialty Centers (DSC) and Regional Dental Prosthesis Laboratories (RDPL). As a device of an HCN, the DSC have territorial orientation with the population base established by law and preferentially obeying the Regionalization Master Plan (RMP). In contrast to a great advance with regard to primary health care, the system is slow in implementing the DSC, an at present there are many gaps in providing care.

In small-sized municipalities, the constitution of Oral Health Care Networks (OHCN) demands the need of regional arrangement. The region of Guanhães, according to the Regionalization Master Plan (RMP) is composed of 11 municipalities with a low population size ${ }^{7}$ that have no reference for specialized oral health care in the public network. For this population, access to secondary oral health care procedures is obtained only in the private network, which excludes persons who have no means to bear the treatment costs. In view of the lack of a device for offering specialized care in the public network, professionals responsible for primary care rarely record this need, causing a complete absence of data about the demand at the level of secondary oral health care. Furthermore, there are no records about outcomes that have occurred in each municipality relative to the needs observed by the Primary Health Care (PHC) professionals.

Therefore, the intention of the present study was to find out the demand for and access (outcome) to the following procedures: dental prosthesis, endodontics, periodontics, care of patients with special needs, surgery, orthodontics and stomatology in the municipalities in the Guanhães region; identify the profiles of the professionals responsible for care of the users in primary care, and characterize the sociodemographic profile of the users that present needs for specialized procedures.

\section{METHODS}

A cross-sectional study was conducted to analyze the demand for and access to specialized oral health procedures. The dependent variables studies were as follows: the need for referral to secondary care in Dental Prosthesis, Endodontics, Stomatology, care of patients with special needs, Oral Surgery, Orthodontics and Periodontics; the conduct adopted by professionals in cases of need represented by referral to the public network, referral to the private network and non-referral and outcome that occurred as a result of the need for specialized care identified. The independent variables related to the Dental Surgeon (DS) were the time since graduation, specialty and time of inclusion in Family Health care. The variables related to the profile of patients were: sex, age, educational level, and situation of rural or urban domicile.

To obtain the variables relative to the profile of patients and DSs, the demand for specialized attention presented and the outcome that occurred from the time of indication for the specialized procedure, an instrument was prepared for data collection. This instrument was organized in files that had a cover, tutorial and the data collection sheets themselves. Definition of the demand for specialized care was determined as instructed in the Basic Care Booklet No.178. In addition to the tutorial, to guarantee uniformity relative to enabling understanding by the research participants, and the information to be collected, local training workshops were scheduled for data collection in each municipality. The data collection 
instrument was tested in Primary Health Care Units (PHCUs) in the municipalities of Belo Horizonte, Salto da Divisa, Sabinópolis and Rio Vermelho.

\section{Study site characterization}

The study was conducted in 10 municipalities of the Guanhães region, considering RMP/MG - 2014, which together have a population of 99,245 inhabitants. All the municipalities were of a small size. The most populated city was Guanhães, with 33,815 inhabitants, pole of medium and high complexity care for the smaller municipalities. The Mean Human Development Index (MHDI) of the region was 0.618 ( $\mathrm{cv}=0.002)$. The mean value of results found in the municipalities for the $\mathrm{GINI}$ index was 0.517 ( $\mathrm{cV}=0.001$ ). The urbanization rate of the studied municipalities showed a mean value of $50.49 \%(c v=0,02)$. The urban population in $50 \%$ of the municipalities corresponded to up to $48.68 \%$. In the year 2010 , the income in this regions presented a median of $R \$ 346.96$ (minimum wage in 2010 $=R \$ 510.00)$. The mean per capita income ranged from $R \$$ 221.79 (minimum) to $R \$ 549.03$ (maximum), with the latter value being found in the only municipality in the region that presented a value higher than that of the minimum wage. The illiteracy rate of the population over the age of 15 years in the municipalities of the region in question presented a mean value of $19.0 \%$ with a minimum of $11.6 \%$ and maximum of $28.6 \%{ }^{9-10}$.

The coverage of the Family Health Team (FHT) presented a mean of $98.75 \%$. As regards the oral health coverage in primary care, 3 municipalities had a coverage of under $100 \%$. Of the 9 municipalities that had an Oral Health Team (OHT) included in the Family Health Team (FHT), according to the model proposed by the NOHP, 6 began their inclusion over 10 or more years ago. The coverage of supervised toothbrushing showed a median of $1.74 \%$, whereas, for the 1 st scheduled dental consultation the lowest value found was $3.04 \%$ and the highest $16.13 \%$, with a median of $12.33 \%$. The percentage of permanent tooth extractions in comparison with the other individual dental procedures, the municipalities presented a median of $7.25 \%$, with the minimum attained being 5.49 and maximum, 15.03. The higher proportion reflected the organization of the services directed toward individual and mutilating curative actions.

\section{Data collection}

Data collection in the municipalities occurred from July to November 2016, with the participation of dental surgeons responsible for oral health care in the Public Health Care (PHC) teams. Data relative to the municipalities were surveyed taking as reference the month 07/2016. The description of data collection is presented in Figure 1.

The data collected were statistically analyzed by using the Program SPSS for Windows, version 18.0. This study was approved by the Research Ethics Committee of the Federal University of Minas Gerais (UMFG) (Report No. $615,701)$

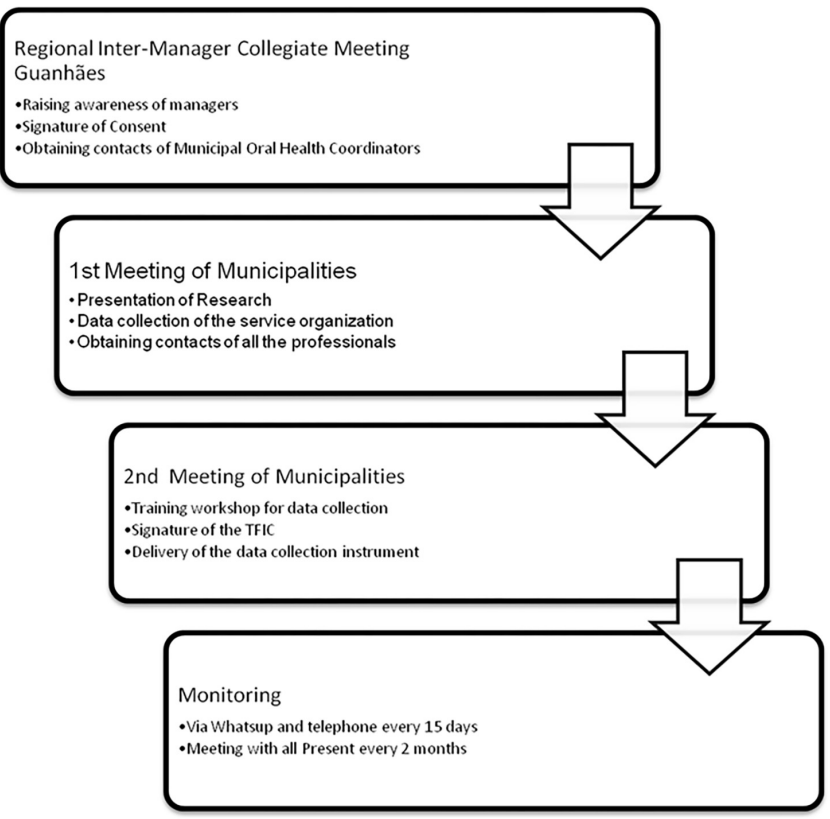

Figure 1. Diagram showing data collection

\section{RESULTS}

\section{Profile of PHC dentists}

Of the 32 professionals who participated in the training workshop, and received the data collection instrument, 02 were excluded because they desisted from participating in the study, and the remainder worked in 27 PHC units distributed throughout the 10 municipalities. The time since the dentists graduated ranged from 1 to 41 years, and $60 \%$ of them had graduated at least 13 years ago; $26.7 \%$ reported being a specialist: family health (2), pediatric dentistry (1), dental prosthesis (1), collective health (1), orthodontics (2) and endodontics (2). The time of inclusion in the Oral Health Team (OHT) ranged from 0 to 14 years, with a median of 3 years. 


\section{Characterization of patients' profile}

A total of 1085 patients were evaluated, with need of secondary care in the following specialties: Dental Prosthesis, Endodontics, Stomatology, care of patients with special needs, Oral Surgery, Orthodontics and Periodontics. Of the 1085 patients, 614 (56.6\%) were of the female sex; $38(3,5 \%)$ were persons with special needs. The distribution of patients per age-ranges and educational level is presented in Table 1.

The majority of the patients resided in the urban zone (59.6\%); $39.8 \%$ in the rural zone, and $0.6 \%$ had no domicile situation indicated.

Table 1. Patients with need of secondary oral health care per age-group and educational level.

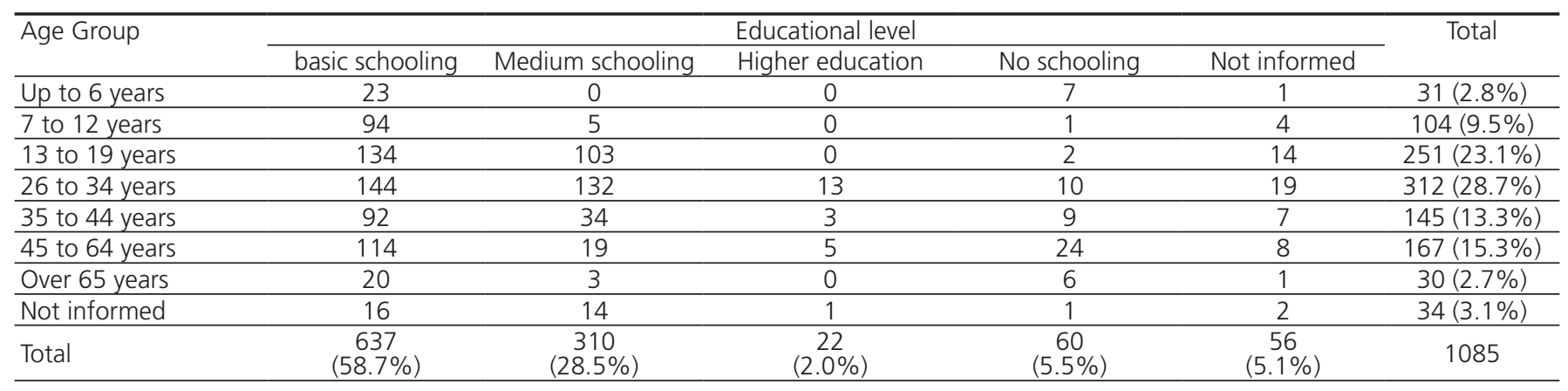

\section{Characterization of demand for secondary care in oral health}

The need of dental prostheses was present in 248 (22.8\%) patients. Of these 91 (8.4\%) needed complete dentures and $164(15.1 \%)$ partial dental prostheses; some of them needed complete and partial dental prostheses. Of those who needed dentures, the majority were in the agerange from 45 to 64 years ( $43.5 \%)$, followed by the agerange from 35 to 44 years (26.7\%); and $4.74 \%$ in the age range from 13 to 19 years.

The specialty with the highest number of indications was endodontic treatment with $662(61 \%)$ patients, and in $606(91.5 \%)$ of them, permanent teeth were involved. The tooth most affected was the first molar in 286 (43.2\%) cases. Patients of up to 19 years old represented 228 (34.4\%) of the indications for this specialty, indicating they were affected at an early age. The distribution of permanent teeth affected per age-ranges is presented in Table 2.

Table 2. Type of permanent tooth affected - per age group

\begin{tabular}{|c|c|c|c|c|c|c|}
\hline \multirow[t]{2}{*}{ Age Group } & \multicolumn{5}{|c|}{ Type of tooth affected } & \multirow[t]{2}{*}{ Total } \\
\hline & $\begin{array}{c}\text { Anterior } \\
\text { Permanent }\end{array}$ & $\begin{array}{l}\text { Permanent } \\
\text { Premolar }\end{array}$ & Permanent 1st molar & $\begin{array}{c}\text { Permanent } 2 \text { nd } \\
\text { molar }\end{array}$ & $\begin{array}{c}\text { Permanent 3rd } \\
\text { molar }\end{array}$ & \\
\hline Up to 6 years & 1 & 0 & 0 & 0 & 0 & $\begin{array}{c}1 \\
(0.2 \%) \\
\end{array}$ \\
\hline 7 to 12 years & 3 & 1 & 40 & 2 & 1 & $\begin{array}{c}47 \\
(7.8 \%) \\
\end{array}$ \\
\hline 13 to 19 years & 24 & 18 & 107 & 31 & 0 & $\begin{array}{c}180 \\
(29.7 \%) \\
\end{array}$ \\
\hline 35 to 44 years & 15 & 21 & 18 & 12 & 1 & $\begin{array}{c}67 \\
(11.1 \%) \\
\end{array}$ \\
\hline 45 to 64 years & 10 & 13 & 17 & 10 & 0 & $\begin{array}{c}50 \\
(8.3 \%) \\
\end{array}$ \\
\hline Over 65 years & 0 & 2 & 0 & 0 & 0 & $\begin{array}{c}2 \\
(0.3 \%)\end{array}$ \\
\hline Without information & 3 & 4 & 10 & 4 & 0 & $\begin{array}{c}21 \\
(3.5 \%) \\
\end{array}$ \\
\hline
\end{tabular}

Periodontal treatment was indicated for 31 patients $(2.9 \%)$ with the majority being concentrated in two age-ranges: 35 to 44 years, $11(35.5 \%)$; and 45 to 54 years, $10(32.3 \%)$. Up to 12 years of age, there were 
no referrals for periodontal treatment, and only 1 in the age-range from 13 to 19 years. Care of patients with special needs was indicated for $16(1.5 \%)$ patients. Oral surgery was indicated for $66(6.1 \%)$ patients, in the age-ranges from 13 to 19 , with 16 (24.2\%) indications; and from 20 to 34, 27 (40.9\%) indications. There were $120(11 \%)$ patients indicated for orthodontic treatment, with a higher number in the age-ranges from 7 to 12 years, $33(27.5 \%)$; and 13 to 19 years, $48(40 \%)$. Only $3(0.3 \%)$ patients presented need of the stomatology specialty.

Of the 1085 patients with indication for secondary oral health care, 836 were referred, with 805 being referred to the private network, and 31 referred to the public network for treatment.

The outcome that occurred from the needs were recorded for 435 (40.1\%) cases, with these being 198 extractions; 86 treatments performed at the unit itself; 5 treatments performed by SUS accredited service; 78 treatments performed at private establishments, and 68 others.

The outcome data were cross-checked with the two most frequent needs: dental prosthesis and endodontic treatment. The data are presented in Table 3.

Table 3. Outcome for endodontic treatment and dental prostheses needs.

\begin{tabular}{|c|c|c|c|c|c|c|c|}
\hline Need & $\begin{array}{l}\text { Number of } \\
\text { patients }\end{array}$ & Extraction & $\begin{array}{l}\text { Performed at the unit } \\
\text { itself }\end{array}$ & $\begin{array}{l}\text { Performed at } \\
\text { accredited SUS } \\
\text { service }\end{array}$ & $\begin{array}{l}\text { Performed at } \\
\text { private service }\end{array}$ & Other & $\begin{array}{c}\text { Without } \\
\text { information }\end{array}$ \\
\hline Endodontics & 662 & $185(27.9 \%)$ & $1(0.2 \%)$ & $1(0.2 \%)$ & $47(7.1 \%)$ & $24(3.6 \%)$ & $404(61.0 \%)$ \\
\hline $\begin{array}{l}\text { Dentures/ } \\
\text { Dental } \\
\text { prosthesis }\end{array}$ & 248 & $10(4.0 \%)$ & 78 (31.5\%) & 0 & $12(4.8 \%)$ & 22 (8.9\%) & $126(50.8 \%)$ \\
\hline
\end{tabular}

\section{DISCUSSION}

The socioeconomic indicators found and the absence of DSCs corroborate the findings of study ${ }^{11}$ that showed a higher percentage of these devices in municipalities with over a 100 thousand inhabitants and HDI of over 0.7. The NOHP is unquestionably an advancement in oral heal in Brazil, however there are differences and/or regional specificities that prevent the effectuation of the policy as it was foreseen in its guidelines. The state of Minas Gerais has established the regional implementation of the DSC, and this process in municipalities with such a small population demands the articulation of many managers, in addition to the need for counting the costs of transport of these patients, which must fall on the municipalities of origin, the majority of which have low income.

The socioeconomic indicators of the region allowed the authors of this study to affirm that many patients had no means of bearing the costs of a trip, or various trips to the headquarter municipality of the region. With an extensive rural area, municipal roads in a poor state of conservation, accessibility to the headquarter municipality of origin presented serious limitations. Considering the focus of approach to accessibility proposed by Vargas et al (2012), in this context: the geographic, functional or technical and economic could be verified ${ }^{12}$. The non- existence of a secondary oral health care device corresponds to the functional or technical focus. "The mere existence or availability of a service does not guarantee accessibility" so that it is necessary to consider geographic factors (means of transport, traveling time and distance), financial accessibility or capability of payment (payment for the use of the service), cultural accessibility or acceptability and functional accessibility or availability, and information ${ }^{13-15}$. According to the definition of the organization of Oral Health Care Networks (OHCNs) in Minas Gerais (MG), the Dental Specialty Centers (DSCs) must be regional, or in specific cases, in an extended region. Although there are some reference DSCs in the region surrounding Guanhães, these are situated at a geographical distance that limits access to them ${ }^{16}$.

The studied Municipalities have invested in extending the coverage of Primary Health Care (PHC) and Oral Health, which means an important strategy for the workings of a health system in a network ${ }^{17}$. The number of first consultations tended to impact on the smaller extraction/ procedures ratio, in the same way as a larger number of collective activities was related to a lower number of extractions in patients under 14 years of age. The fact has to be considered that in Minas Gerais, a considerable number of specialized procedures in oral health were performed in primary health care $(\mathrm{PHC})$ units ${ }^{18-19}$ although in this study only the treatment with dental prostheses performed in the 
PHC was found.

The need most commonly referred to the Dental Specialty Centers (DSCs) by Brazilian oral health teams was Endodontics (68.4\%)20 coinciding with the results of this research (61\%). The majority of endodontic problems result from the progression of untreated caries disease, a condition frequently related to situations of greater vulnerability, such as the parents' number of years of schooling, family income ${ }^{21}$, situation of rural domicile, not being a student and $\mathrm{HD}^{22-23}$. The size of the municipal population showed a positive relationship with the number of endodontic procedures performed. In the same way, a higher income was related to a higher rate of having any other specialized oral health procedure performed ${ }^{24}$.

The need for removable dentures was met by the primary care team, which may be associated with the existence of a Removable Dental Prosthesis Laboratory (RDPL) in 5 municipalities in this region. The offer of dental prostheses in PHC appeared as an answer to the edentulism present, as a priority, in the population of adults and older persons, and made the integrality of care possible.

The region of Guanhães contains municipalities that present unfavorable socioeconomic indicators and a good coverage of oral health teams, factors probably related to the outcome most frequently found; that was extraction. Studies have shown that indicators such as the HDI, GINI and greater coverage by the FHT/OHT are negatively related to the proportion of extractions ${ }^{17,25}$. Extraction continues to be the most resolutive treatment for persons with low income ${ }^{26}$.

The large number of unrecorded outcomes (without information) reflected the limitation of the time of study (5 months) and the difficulty of primary care teams in coordinating care. Establishment of a closer relationship with the population, and getting to know its characteristics is the fundamental role of $\mathrm{PHC}$ in the Health Care Network $(\mathrm{HCN})^{4}$. Encouraging resolutive primary care capable of reducing the demand for specialized services is a challenge placed before the National Oral Health Plan (NOHP) ${ }^{20}$.

As regards the limitations of the study, the authors could point out: the reduced period of time for data collection and difficulty related to recording the outcome, and follow-up of patients after care was provided.

\section{REFERENCES}

1. Brasil. Constituição de 1988 de 5 de Outubro de 1988. Constituição da República Federativa do Brasil. Brasília: Senado Federal; 1988 [citado 2017 Jun 14]. Disponível em: < http://

\section{CONCLUSIONS}

The present study showed the specificities of the Guanhães region that has no secondary oral health care device. The need of secondary attention by patients that seek dental treatment at the OHT and Public Health Care (PHS) and the outcomes found in the period of study reflected the municipal socioeconomic indicators and offer of services found.

The National Oral Health Program (NOHP) is a proposal to change the model of care. Therefore, for including it as a public policy, seeking to guarantee the right to health, and achieve integrality, it would be fundamental to have an integrated system at its different levels of care (primary care, specialized and hospital/rehabilitation).

This is fundamental, because a public oral health policy should be capable of recognizing the peculiarities of each region and consider them in the structuring, organization and management of the health system.

For this purpose, it would perhaps be necessary to think of two important questions in relation to the offer of and access to specialized services in the region: a) increase the scope of offer of procedures in primary care in oral health, comprising procedures that extend the resolutive capacity of this level of care; b) create municipal specialized services, smaller than those of the Dental Specialties Centers (DSC), but with the capacity to resolve the demands for specialized treatment in each municipality or health region.

\section{Collaborators}

WCLB COSTA was responsible for the design, data collection, analysis and interpretation of the data, writing the article and approval of the final version of the manuscript. MAF WERNECK and AC PALMIER were responsible for the design, analysis and interpretation of the data, critical review relevant to the intellectual content and approval of the final version of the manuscript

www2.camara.leg.br/legin/fed/consti/1988/constituicao-19885-outubro-1988-322142-publicacaooriginal-1-pl.html>.

2. Brasil. Lei n. 8.080 de 19 de setembro de 1990. Dispõe sobre as condições para a promoção, proteção e recuperação da saúde, a organização e o funcionamento dos serviços correspondentes e dá outras providências. Diário Oficial da União, 20 set 1990 
[citado 2017 Jun 14]. Disponível em: <http://dtr2004.saude.gov. br/susdeaz/legislacao/arquivo/04_lei_8080.pdf.> .

3. Brasil. Portaria n. 4.279 de 30 de dezembro de 2010. Estabelece diretrizes para a organização da Rede de Atenção à Saúde no âmbito do Sistema Único de Saúde (SUS). Diário Oficial da União, 31 dez 2010 [citado 2017 Jun 14]. Disponível em: <http:// conselho.saude.gov.br/ultimas_noticias/2011/img/07_jan_ portaria4279_301210.pdf>.

4. Mendes EV. As redes de atenção à saúde. Ciênc. Saúde Coletiva. 2010;15(5):2297-2305. doi: 10.1590/S141381232010000500005

5. Brasil. Ministério da Saúde. Secretaria de Atenção a Saúde. Departamento da Atenção Básica. Diretrizes da política nacional de Saúde Bucal. Brasília: Ministério da Saúde; 2004. [citado 2017 Jun 14]. Disponível em: <http://189.28.128.100/dab/docs/ publicacoes/geral/diretrizes_da_politica_nacional_de_saude_ bucal.pdf>.

6. Brasil. Portaria n. 599/GM de 23 de março de 2006. Define a implantação de Especialidades Odontológicas (CEOs) e de Laboratórios Regionais de Próteses Dentárias (LRPDs) e estabelecer critérios, normas e requisitos para seu credenciamento. Diário Oficial da União, 24 Jun 2010 [citado 2017 Jun 14]. Disponível em: <http://dtr2001.saude.gov.br/sas/PORTARIAS/Port2006/ GM/GM-599.htm>.

7. Minas Gerais. Plano Diretor de Regionalização (2014) [citado 2017 Jun 14]. Disponível em: <http://www.saude.mg.gov.br/ images/anexos/PDR/Adscricao-munici-micro-macro-pdr-2014. pdf>.

8. Brasil. Ministério da Saúde. Secretaria de Atenção à Saúde. Departamento de Atenção Básica. Saúde Bucal. Cadernos de Atenção Básica, n. 17. Brasília: Ministério da Saúde, 2006 [citado 2017 Jun 14]. Disponível em: <http://bvsms.saude.gov. br/bvs/publicacoes/saude_bucal.pdf>.

9. Instituto Brasileiro de Geografia e Estatística [homepage na internet [citado 2017 Jun 12]. Disponível em: <http:www.ibge. gov.br>.

10. Departamento de Informática do SUS [homepage na internet] [citado 2016 Set 10]. Disponível em: <www.datasus.gov.br>.

11. Goes PSA, Figueiredo N, Neves JC, Silveira FMM, Costa JFR, Pucca Júnior GA et al. Avaliação da atenção secundária em saúde bucal: uma investigação nos centros de especialidades do Brasil. Cad Saúde Pública. 2012;28(Suppl):s81-s89. Doi: 10.1590/S0102-311X2012001300009

12. Vargas AMD, Ferreira EF, Mattos FF, Vasconcelos M, Drumond MM, Lucas SD. O acesso aos serviços públicos de saúde em área limítrofe entre municípios. Saude soc. 2011;20(3):821-828. doi: 10.1590/S0104-12902011000300024

13. Bulgareli JV, Faria ET, Ambrosano GMB, Vazquez FL, Cortellazzi $\mathrm{KL}$, Meneghim MC et al. Informações da atenção secundária em Odontologia para avaliação dos modelos de atenção à saúde. Rev Odontol UNESP. 2013;42(4):229-236. doi: 10.1590/S180725772013000400001

14. Assis MMA, Jesus WLA. Acesso aos serviços de saúde: abordagens, conceitos, políticas e modelo de análise. Ciênc Saúde Coletiva. 2012;17(11):2865-2875. doi: 10.1590/S141381232012001100002
15. Sanchez RM, Ciconelli RM. Conceitos de acesso à saúde. Rev Panam Salud Publica. 2012;31(3):260-268.

16. Comissão Intergestores Bipartite (MG). Deliberação 1676 (2013) [citado 2016 Set 10]. Disponível em: <http://www.saude.mg.gov. br/images/documentos/Del\%201676\%20-\%20Institui\%20 a \% 20 rede $\% 20$ de $\% 20$ aten \% C 3 \% A 7 \% C 3 \% A 3 o \% 20 \%C3\%A1\%20sa\%C3\%BAde\%20bucal.pdf>.

17. Lavras C. Atenção primária à saúde e a organização de redes regionais deatençãoàsaúdeno Brasil. SaudeSoc. 2011;20(4):867874. doi: 10.1590/S0104-12902011000400005.

18. Fernandes LS, Peres MA. Associação entre atenção básica em saúde bucal e indicadores socioeconômicos municipais. Rev Saúde Pública. 2005:39(6):930-936. doi: 10.1590/S003489102005000600010

19. Lino PA, Werneck MAF, Lucas SD, Abreu MHNG. Análise da atenção secundária em saúde bucal no estado de Minas Gerais, Brasil. Ciênc Saúde Coletiva. 2014;19(9):3879-3888. doi: 10.1590/1413-81232014199.12192013

20. Martins RC, Reis CMR, Machado ATGM, Amaral JHL, Werneck MAF, Abreu MHNG. Relationship between Primary and secondary dental care in public health services in Brazil. PLoS ONE. 2016;11(10):e0164986.

21. Gonçalves ER, Peres MA, Marcenes W. Cárie dentária e condições sócio-econômicas: um estudo transversal com jovens de 18 anos de Florianópolis, Santa Catarina, Brasil. Cad Saúde Pública. 2002;18(3):699-706. doi: 10.1590/S0102$311 \times 2002000300013$

22. Frias AC, Antunes JLF, Junqueira SR, Narvai PC. Determinantes individuais e contextuais da prevalência de cárie dentária não tratada no Brasil. Rev Panam Salud Publica. 2007;22(4):279285.

23. Mello TRC, Antunes JLF, Waldman EA. Prevalência de cárie não tratada na dentição decídua em áreas urbanas e rurais do Estado de São Paulo, Brasil. Rev Panam Salud Publica. 2008;23(2):7884.

24. Celeste RK, Moura FRR, Santos CP, Tovo MF. Análise da produção ambulatorial em municípios com e sem centros de especialidades odontológicas no Brasil em 2010. Cad Saúde Pública. 2014;30(3):511-521. doi: 10.1590/0102-311X00011913

25. Godoi H, Mello ALSF, Caetano JC. Rede de atenção à saúde bucal: organização em municípios de grande porte de Santa Catarina, Brasil. Cad Saúde Pública. 2014;30(2):318-332. doi: 10.1590/0102-311X00084513

26. Soares FF, Chaves SCL, Cangussu MCT. Desigualdade na utilização de serviços de saúde bucal na atenção básica e fatores associados em dois municípios brasileiros. Rev Panam Salud Publica. 2013;34(6):401-406. 